\title{
Television Viewing Behaviour among Rural Youths
}

\author{
Geetu Thokchom $^{1 *}$, Aheibam Tarajit Singh ${ }^{2}$, Rebani Akoijam ${ }^{3}$ and Talsia Mangsidam ${ }^{1}$ \\ ${ }^{1}$ Pandit Deen Dayal Upadhyay Institute of Agricultural Sciences, \\ Utlou, Bishnupur, Manipur, India \\ ${ }^{2}$ KVK Utlou, Bishnupur, Manipur, India \\ ${ }^{3} \mathrm{COA}, \mathrm{CAU}$, Manipur, India \\ *Corresponding author
}

\section{A B S T R A C T}

\section{Keywords}

Television viewing behaviour, Rural youths

\section{Article Info}

Accepted:

22 October 2020

Available Online:

10 November 2020
The present study was carried out in the 4 villages of Patsoi sub division of Imphal West district of Manipur. The study was undertaken to ascertain the reasons influencing the television viewing behaviour and to determine the relationship between the personal, social and economic characteristics and television viewing behaviour of the youths. A total sample of 100 youths having attending the age of between 18 to 35 years including from schools, school dropout or both residing in the same villages was selected. An interview scheduled was developed and used to collect requisite information pertaining to the objectives of the study. The data were collected from the youths using face to face interview schedule. The pretesting of the interview schedule was done and necessary correction were made in the parameters i.e, age, education, family type, gender, occupation, parental background, marital status, participation in outdoor activities, channel preference, programme preference, time of watching, duration of watching and viewing habits. The result of the study revealed that of the eight independent variables, three variables that is education, family type and occupation were found to be positively significant, three variables marital status, gender and parental background were nonsignificant and age, participation in outdoor activities were found to be negatively significant. All the independent variables were taken for multiple regression analysis to estimate their predictive abilities. Out of the eight independent variables, age and education may be termed as a good predictor of the television viewing behaviour. Age category emerged as the most significant followed by education were also significant $(b=369),(b=361)$ respectively. The $\mathrm{R}^{2}$ value being 0.692 shows that $69.2 \%$ of the data are found to be correct. The $\mathrm{F}$ value being 19.41 are also significant at 0.05 level of probability.

\section{Introduction}

Television plays a very important role in everyday lives and has a strong influence in building the youths. There are lots of positive aspects while watching television. The youths receive a vast amount of information and knowledge from television. Since every 
individual depends on some kind of media for the latest news and updates, it is the best way to bring awareness in the society. Television was introduced on 15 September 1959 as an experimental basis for ten years in view of its potential for development communication, it soon turned out to be an entertainment medium and its spread was more in the cities than in the villages. But now it has been available in every household in India. Many scholars have expressed their concerns on negative effects of television on children's learning and their socialization. Devadas and Saravanan (2015) found that TV is successful in making women literate, helps in children's education, making ware about family schemes and providing knowledge about sports. Dutra GF et al., (2015) reported that 58\% of the respondents preferred indoor activities rather than outdoor activities because they didn't want to miss their favorite programme in the TV.

Young people, in particular have very malleable minds and are greatly affected by the things they see on the television. Ritchie et al., (1987) revealed that quality and quantity of the impact of television content depended upon the ages of the viewer. Ramana and Krishna (2014) found that most of the people around the age 20-35 age group watch television at night. With increase in age, there is a significant change in the pattern of television viewing.

Television occupies an important place in our life. It is considered to be one of the cheapest modes of audio visual entertainment. Goodhard et al., (1987) found that both male and female varied in their behavior of exhibiting cultured learned from television. Thanks to the technological revolution and its diffusion to the third world countries, as a medium of mass communication set, has become an essential ingredient in the modern and dynamic society. Television is perhaps the most widely debated medium of communication all over the world. The developed world is concern with the public addiction to it and the developing world is fast catching up with the fantasies of the small screen which brings news and views, triumphs and traumas, celebration and strategies, live or recorded, to the living room from every corner of the globe. Nielson (2012) found that out of different programs that are available for viewing including news, entertainment, educational, informative and advertisements, entertainment dominates primetime viewership.

Television viewing frequently limits youth's time for vital activities such as playing, reading, learning to talk, spending time with peers and family, storytelling, participation in regular exercise, and developing another necessary physical, mental and social skills. Still watching television takes time away from reading and schoolwork. Sharif I et al., (2010) revealed that time spent on media use could simply displace time spent doing outdoor activities that promote academic performance.

Today, television is considered to be a major source of entertainment and learning for many, especially the young. All the television programs especially commercial, news, documentaries and cartoons affect people of all ages in different ways. Youngsters constitute one of the groups in society who spend a lot of time watching television.

\section{Materials and Methods}

The investigator selects the state of Manipur where her residence is there, familiar with the area and convergent with the people as well as officials. The next was the selection of district in which Imphal West district was purposively selected as the researcher belong to the same region of the state and moreover when pilot study was done, she found that the people are ready to share the information 
freely. The district is divided into four subdivision: Lamphelpat, Wangoi, Lamshang and Patsoi and only one sub division is selected. Out of the total number of population of Patsoi, four villages are selected by simple random sampling and out of the four no of villages, a total of 100 respondents are selected again by simple random sampling. The primary data were collected directly from the respondents with the help of structured schedule through personal interview method. The data analysis was done by using statistical methods which were frequency, percentage, standard deviation, correlation, regression and $\mathrm{F}$ test.

\section{Results and Discussion}

\section{Television viewing behavior of rural youths}

It was found that majority of the youths in the sample had preferred both local and non-local i.e., $79 \%$ following by local channels $14 \%$ and the least belonged to non-local channels $7 \%$. In case of programme preference highest percentage fell under entertainment 54\% followed by news $26 \%$, sports $16 \%$ and the least percentage fell under educational programme $4 \%$. Most of the respondents that is $78 \%$ likes to watch television during night time followed by evening time $10 \%$ and morning time $4 \%$. In case of duration of watching, highest percentage fell under respondents viewing television less than 2 hours i.e., $55 \%$ followed by more than 2 hours but less than 5 hours i.e., $35 \%$ and the least percentage fell under more than 5 hours $10 \%$ (Table 1).

\section{Relationship between the personal and socio-economic characteristics of the rural youths with their television viewing behavior}

Correlation coefficient between the dependent variables and the TV viewing behavior of rural youths helps in getting the idea about the relationship of dependent variables with the independent variables for the TV viewing behavior.

The study revealed (Table 2) that the age of the youths was found to be negatively significant with the television viewing behaviour having ' $r$ ' value -0.626 . This might be because senior youths are more involved in household activity as compared to junior youths. Education was found to be positively significant at 0.01 level of probability having ' $r$ ' value 0.268 which shows that higher the education leads to increase in television viewing behavior of the respondents. This might be because they are able to gain important knowledge from the TV. Family type shows positively significant at 0.01 level of probability having ' $r$ ' value 0.263 and this shows that either nuclear or joint, the television viewing behavior increases. Gender was found to be positive and non significant with the television viewing behavior showing that gender was not significant in respect of the television viewing behavior. The correlation coefficient between the marital status and television viewing behavior of the rural youths were found to be non significant having ' $r$ ' value -0.101 . This means that marital status is not interrelated with television viewing behavior. Occupation showed positive significant at 0.05 level of probability having ' $r$ ' value 0.216 . This shows that regardless of the respondents, the television viewing behavior increases. Parental background was found to be non significant having ' $r$ ' value 0.041 . This shows that parental background is not interrelated with television viewing behavior of the respondents. Participation in outdoor activity were found to be negatively significant with the television viewing behavior at 0.01 level probability having ' $r$ ' value -0.149 . It can be concluded that higher the participation in outdoor activities lower in the level of television viewing behavior of the respondents. 
Table.1 Distribution of respondents under different sub variables for television viewing behavior of rural youths

\begin{tabular}{|c|c|c|}
\hline Sl. No. & $\begin{array}{l}\text { Selected sub variables for television viewing behavior of } \\
\text { rural youths (dependent variable) }\end{array}$ & Total (\%) \\
\hline 1. & $\begin{array}{l}\text { Channel preference } \\
\text { a) Local channels } \\
\text { b) Non-local channels } \\
\text { c) Both channels }\end{array}$ & $\begin{array}{l}14(14) \\
7(7) \\
79(79)\end{array}$ \\
\hline 2. & $\begin{array}{l}\text { Program preference } \\
\text { a) Educational } \\
\text { b) News } \\
\text { c) Sports } \\
\text { d) Entertainment }\end{array}$ & $\begin{array}{l}4(4) \\
26(26) \\
16(16) \\
54(54)\end{array}$ \\
\hline 3. & $\begin{array}{l}\text { Time of watching } \\
\text { a) Morning time } \\
\text { b) Evening time } \\
\text { c) Night time }\end{array}$ & $\begin{array}{l}4(4) \\
18(18) \\
78(78)\end{array}$ \\
\hline 4. & $\begin{array}{l}\text { Duration of watching } \\
\text { a) Less than } 2 \text { hours } \\
\text { b) More than } 2 \text { hours but less than } 5 \text { hours } \\
\text { c) More than } 5 \text { hours }\end{array}$ & $\begin{array}{l}55(55) \\
35(35) \\
10(10)\end{array}$ \\
\hline 5. & $\begin{array}{l}\text { Viewing habits } \\
\text { a) Individual } \\
\text { b) Group }\end{array}$ & $\begin{array}{l}22(22) \\
78(78)\end{array}$ \\
\hline
\end{tabular}

Table.2 Correlation coefficient between television viewing behavior of rural youths and independent variables

\begin{tabular}{|c|l|}
\hline Independent Variables & Correlation coefficients ( r ) \\
\hline 1. Age & $-0.626^{*}$ \\
\hline 2. Education & $0.268^{* *}$ \\
\hline 3. Family type & $0.263^{* *}$ \\
\hline 4. Gender & $0.091(\mathrm{NS})$ \\
\hline 5. Marital status & $-0.101(\mathrm{NS})$ \\
\hline 6. Occupation & $0.216^{*}$ \\
\hline 7. Parental background & $0.041(\mathrm{NS})$ \\
\hline 8. Participation in outdoor activities & $-0.149^{* *}$ \\
\hline
\end{tabular}

**-Significant at 0.01 level of probability

*-Significant at 0.05 level of probability

NS - Non significant 
Table.3 Multiple regression coefficients for television viewing behavior of rural youths and independent variables

\begin{tabular}{|l|l|c|c|}
\hline Sl. No. & Independent variable & Regression coefficient & Beta \\
\hline $\mathbf{1 .}$ & Age & 0.001 & 0.369 \\
\hline $\mathbf{2 .}$ & Education & 0.017 & 0.361 \\
\hline $\mathbf{3 .}$ & Family Type & 0.000 & 0.172 \\
\hline $\mathbf{4 .}$ & Gender & 0.082 & -0.037 \\
\hline $\mathbf{5 .}$ & Marital Status & 0.696 & -0.036 \\
\hline $\mathbf{6 .}$ & Occupation & 0.708 & 0.059 \\
\hline $\mathbf{7 .}$ & Parental background & 0.452 & 0.095 \\
\hline $\mathbf{8 .}$ & Participation in outdoor activities & 0.285 & 0.052 \\
\hline $\mathrm{R}^{2}=0.692$ & & & \\
\hline $\mathrm{F}=19.41$ & & & \\
\hline *-Significant at 0.05 level of probability & & \\
\hline
\end{tabular}

Multiple regression coefficients for television viewing behavior of rural youths and independent variables (Table 3). Out of the eight independent variables, age and education may be termed as a good predictor of the television viewing behaviour. Age categories emerged as the most significant followed by education were also significant $(b=369),(b=361)$ respectively. The $\mathrm{R}^{2}$ value being 0.692 shows that $69.2 \%$ of the data are found to be correct. The F value being 19.41 was also found to be significant at 0.05 level of probability.

On the basis of the study conducted, it can be concluded that majority of the rural youths in the sample have medium level of television viewing behavior and medium participation in outdoor activities. The respondents were found to have more contributing characteristics that were good predictors in television viewing behavior of rural youths.

\section{Acknowledgement}

The authors are thankful to the Pandit Deen Dayal Upadhyay Institute of Agricultural Sciences. Utlou, Bishnupur, Manipur for providing all the necessary facilities during the research.

\section{References}

Devadas, D.R. M.B., Saravanan, V.M. (2015). Television and development of rural women-A study, Research WorldJournal of Arts, Science \& Commerce, International Referred Research Journal, www.researchersworld.com, Vol-VI, Issue-4(1), Oct.2015

Gisele, F. Dutra, Christiana, C. Kaufmann, Alessandra, D.B. Pretto, Elaine, P. Albernaz, Television viewing habits and their influence on physical activities and childhood over weight Pediatr (Rio.J), Vol, 91(4), Porto Alege, July/Aug 2015

Goodhardt, G.J., et al., (1987). The Television Audiences-Patterns of Viewing - An update, England: Gower publishing

Imran Sharif, Thomas A Wills, James D Sargent, Effect of visual media use on school performance: A prospective study, J adolese health; 46(1): 52, Jan 2010.

Nielsen. (2012, April 19). Advertising and Audience Part 1: Primetime By Genre. Nielsen.

http://www.nielson.com/content/dam/co rporate/us/en/newswire/uploads/2012/0 4/Nielsen-advertising-and-audiencesspring-2012.pdf 
Ramana, Krishna, S. Hari, (2014): A Study of TV viewership pattern from select respondents of Twin Cities, Volume4, Number 2, April-June 2015, page 15511561/Pezzottaite journals. International
Journal of Applied Services Marketing Perspectives.

Ritchie, et al., (1987). Television reading and reading achievement. Communication Res., 14(3).

\section{How to cite this article:}

Geetu Thokchom, Aheibam Tarajit Singh, Rebani Akoijam and Talsia Mangsidam. 2020. Television Viewing Behaviour among Rural Youths. Int.J.Curr.Microbiol.App.Sci. 9(11): 3044-3049. doi: https://doi.org/10.20546/ijcmas.2020.911.369 